\title{
Transient response method for characterization of active sites in HZSM-5 with low content of iron during $\mathrm{N}_{2} \mathrm{O}$ decomposition
}

\author{
Lioubov Kiwi-Minsker*, Dmitri A. Bulushev, Albert Renken \\ Laboratory of Chemical Reaction Engineering, Swiss Federal Institute of Technology, LGRC-EPFL, CH-1015 Lausanne, Switzerland
}

Available online 24 April 2004

\begin{abstract}
The surface active Fe-sites in HZSM-5 with low content of iron $(<1000 \mathrm{ppm})$ activated by steaming and high temperature (up to $1323 \mathrm{~K})$ calcination in inert lead to the formation of surface oxygen $(\mathrm{O})_{\text {ad }}$ species from $\mathrm{N}_{2} \mathrm{O}$ and were characterized quantitatively by transient response method. Only a part of $(\mathrm{O})_{\text {ad }}$ deposited on zeolite by decomposing $\mathrm{N}_{2} \mathrm{O}$ was active in $\mathrm{CO}$ oxidation at $523 \mathrm{~K}$. A binuclear Fe-center is suggested as an active center, featuring a "diamond core" structure, similar to that of the monooxygenase enzyme. The active O-atoms were assigned to the paired terminal oxygen atoms each bound to one Fe-site in the binuclear $\left[\mathrm{Fe}_{2} \mathrm{O}_{2} \mathrm{H}\right]^{+}$-cluster.

Zeolite pre-saturated by water vapor at $473-523 \mathrm{~K}$ generates $(\mathrm{O})_{\text {ad }}$ species from $\mathrm{N}_{2} \mathrm{O}$ completely inactive in the CO oxidation. The total amount of the oxygen, $(\mathrm{O})_{\text {ad }}$, deposited on the pre-saturated by water zeolite corresponds to a half of stoichiometric amount of the surface $\mathrm{Fe}$-atoms and suggests that water blocks a half of the binuclear $\left[\mathrm{Fe}_{2} \mathrm{O}_{2} \mathrm{H}\right]^{+}$-center, the remaining acting as a single $\mathrm{Fe}$-site.

(C) 2004 Elsevier B.V. All rights reserved.
\end{abstract}

Keywords: Fe-containing HZSM-5; $\alpha$-Oxygen; $\left[\mathrm{Fe}_{2} \mathrm{O}_{2} \mathrm{H}\right]^{+}$diamond core; Monooxygenase; $\mathrm{N}_{2} \mathrm{O}$ decomposition; Transient response method

\section{Introduction}

The nature of active sites in HZSM-5 zeolites with low content of Fe-ions (herein after $\mathrm{H}(\mathrm{Fe}) \mathrm{ZSM}-5$ ) during benzene oxidation to phenol and direct $\mathrm{N}_{2} \mathrm{O}$ decomposition is the focus of much interest. There is a wide consensus concerning the Fe-ions activity, but the specific nature of the active sites, especially the Fe nucleation, remains an open question. Activity was assigned by Panov and co-workers [1] to binuclear iron clusters in the zeolite extra-framework, where each $\mathrm{Fe}^{2+}$-site would be able to generate one active $\mathrm{O}$-atom from $\mathrm{N}_{2} \mathrm{O}$, called $\alpha$-oxygen. This $\alpha$-oxygen was claimed to have high oxidative power converting $\mathrm{CO}$ to $\mathrm{CO}_{2}$, or forming phenol from benzene at low temperatures $[1,2]$. But the experimental evidence for the stabilization of isolated iron cations after zeolite steaming has also to be taken into account $[3,4]$. Besides, the $\mathrm{Fe}^{2+}$-sites were studied experimentally [5], theoretically [6,7] and the DFT calculations of a benzene oxidation assuming mononuclear iron site have been recently published by Kachurovskaya et al. [8].

\footnotetext{
* Corresponding author. Tel.: +41-21-693-31-82; fax: +41-21-693-61-90.

E-mail address: lioubov.kiwi-minsker@epfl.ch (L. Kiwi-Minsker).
}

In spite of significant efforts, the characterization of active sites in $\mathrm{H}(\mathrm{Fe}) \mathrm{ZSM}-5$ materials remains a challenge mainly due to low content of iron. Until now the concentration of active $\mathrm{Fe}$-sites has been measured in a static vacuum set-up from the amount of the $\mathrm{N}_{2}$ released or the $\mathrm{N}_{2} \mathrm{O}$ consumed [1]. Another question: Is every oxygen atom deposited on the surface from $\mathrm{N}_{2} \mathrm{O}$ able to participate in oxidative reactions? Only Panov's group has addressed this point.

We report herein the first application of a transient response method to determine quantitatively the iron active sites concentration starting from a few dozens of ppm. It is important to note that the measurements are carried out under normal pressure and at the reaction temperature. The number of active sites is defined as the number of $\mathrm{N}_{2} \mathrm{O}$ molecules that can be decomposed on the zeolite

$\mathrm{N}_{2} \mathrm{O}+()=(\mathrm{O})_{\mathrm{ad}}+\mathrm{N}_{2}$

We concentrated on answering the two questions: (1) how the pre-treatment of the $\mathrm{H}(\mathrm{Fe}) \mathrm{ZSM}-5$ influences the $(\mathrm{O})_{\mathrm{ad}}$ formation and its activity and (2) has every oxygen atom $(\mathrm{O})_{\mathrm{ad}}$ deposited on the surface from $\mathrm{N}_{2} \mathrm{O}$ the same oxidative power? Activity of the deposited oxygen was characterized by its ability to oxidize $\mathrm{CO}$. 


\section{Experimental}

The hydrothermal synthesis of HZSM-5 $200 \mathrm{Fe}$ has been described in details in our recent publication [9]. It is important to note that iron source was not added to the synthesis solution in order to obtain zeolite samples containing "natural", impurity level of Fe. The deionized water was used in the preparation of HZSM- $5200 \mathrm{Fe}$ with iron concentration of $200 \mathrm{ppm}$ and $\mathrm{Si} / \mathrm{Al}=42$ as measured by atomic absorption spectroscopy in a Shimadzu AA-6650 spectrometer. The HZSM-5 $1000 \mathrm{Fe}$ with $\mathrm{Si} / \mathrm{Al}$ ratio $=25$ was kindly provided by Uetikon SA (Switzerland).

For activation, the samples were pre-treated by steam ( 310 mbar) in nitrogen at $823 \mathrm{~K}$ for $3 \mathrm{~h}$ and calcined in flow of $\mathrm{He}$ for $1 \mathrm{~h}$ at $823 \mathrm{~K}$.

The active sites concentration measurements, reactivity and temperature-programmed (TPD) studies were performed in a Micromeritics AutoChem 2910 analyzer provided with a quartz plug-flow reactor. A ThermoStar 200 (Pfeiffer Vacuum) mass-spectrometer was used to control the composition of gas phase. The catalysts $(1.04-1.09 \mathrm{~g})$ after pre-treatments were cooled down in He to the temperature of the transient response $(523-653 \mathrm{~K})$. The latter was performed by a quick switch of the He flow to the flow of gaseous mixture: 2 vol. $\% \mathrm{~N}_{2} \mathrm{O} / 2$ vol.\% Ar/96 vol. $\%$ He at a flow-rate $20 \mathrm{ml}(\mathrm{STP}) / \mathrm{min}$. $\mathrm{N}_{2} \mathrm{O}$ reacts with the catalyst resulting in the formation of gaseous nitrogen and oxygen bound by the catalyst according to the reaction (1). The amount of active sites was calculated by integration of the nitrogen peak area. In the experiments with water, $\mathrm{H}_{2} \mathrm{O}$ was pulsed to the reactor at $523 \mathrm{~K}$ using a $0.5 \mu$ l syringe via a special injector controlling the sample saturation by the mass-spectrometer.
Reactivity of adsorbed oxygen was characterized by $\mathrm{CO}$ oxidation to $\mathrm{CO}_{2}$ by the catalyst containing $(\mathrm{O})_{\text {ad }}$ deposited from $\mathrm{N}_{2} \mathrm{O}$ at $523 \mathrm{~K}$. The reactor was purged by $\mathrm{He}$ for 15 min after sample interaction with $\mathrm{N}_{2} \mathrm{O}$, temperature was set to $523 \mathrm{~K}$ and the mixture of 3 vol.\% CO in $\mathrm{He}(20 \mathrm{ml}$ (STP)/min) was introduced for $6 \mathrm{~min}$.

\section{Results and discussion}

\subsection{Quantitative determination of Fe-sites by the transient response method}

The gas-phase composition was monitored in the reactor outlet after a step change of gas composition in the reactor inlet. The results for the HZSM-5 $1000 \mathrm{Fe}$ sample are shown in Fig. 1. The non-ideal reactor behavior, as compared to the plug-flow, is represented by the concentration-time profile of an inert tracer (Ar). It is seen from Fig. 1 that besides $\mathrm{N}_{2} \mathrm{O}$ and $\mathrm{Ar}$, also $\mathrm{N}_{2}$ appears indicating the stoichiometric reaction (1) with concomitant formation of $(\mathrm{O})_{\mathrm{ad}} \cdot \mathrm{N}_{2}$ appears simultaneously with Ar. A certain delay (about $35 \mathrm{~s}$ ) is observed for $\mathrm{N}_{2} \mathrm{O}$. It can be concluded that when all active sites are covered by $(\mathrm{O})_{\mathrm{ad}}$, the reaction stops. No molecular oxygen was detected at the outlet since $\mathrm{N}_{2} \mathrm{O}$ decomposition on $\mathrm{N}_{2}$ and $\mathrm{O}_{2}$ starts at higher temperatures (9). The concentration of active Fe-sites $\left(C_{\mathrm{Fe}}\right)$ is estimated from the amount of $\mathrm{N}_{2}$ released and after the standard pre-treatment was $C_{\mathrm{Fe}}=5.8 \times 10^{17}$ molecules/g.

In order to control if the formation of $(\mathrm{O})_{\mathrm{ad}}$ is reversible, after interaction with $\mathrm{N}_{2} \mathrm{O}$ the reactor was purged by $\mathrm{He}$ and the transient response experiment with the $\mathrm{N}_{2} \mathrm{O}$ mixture was

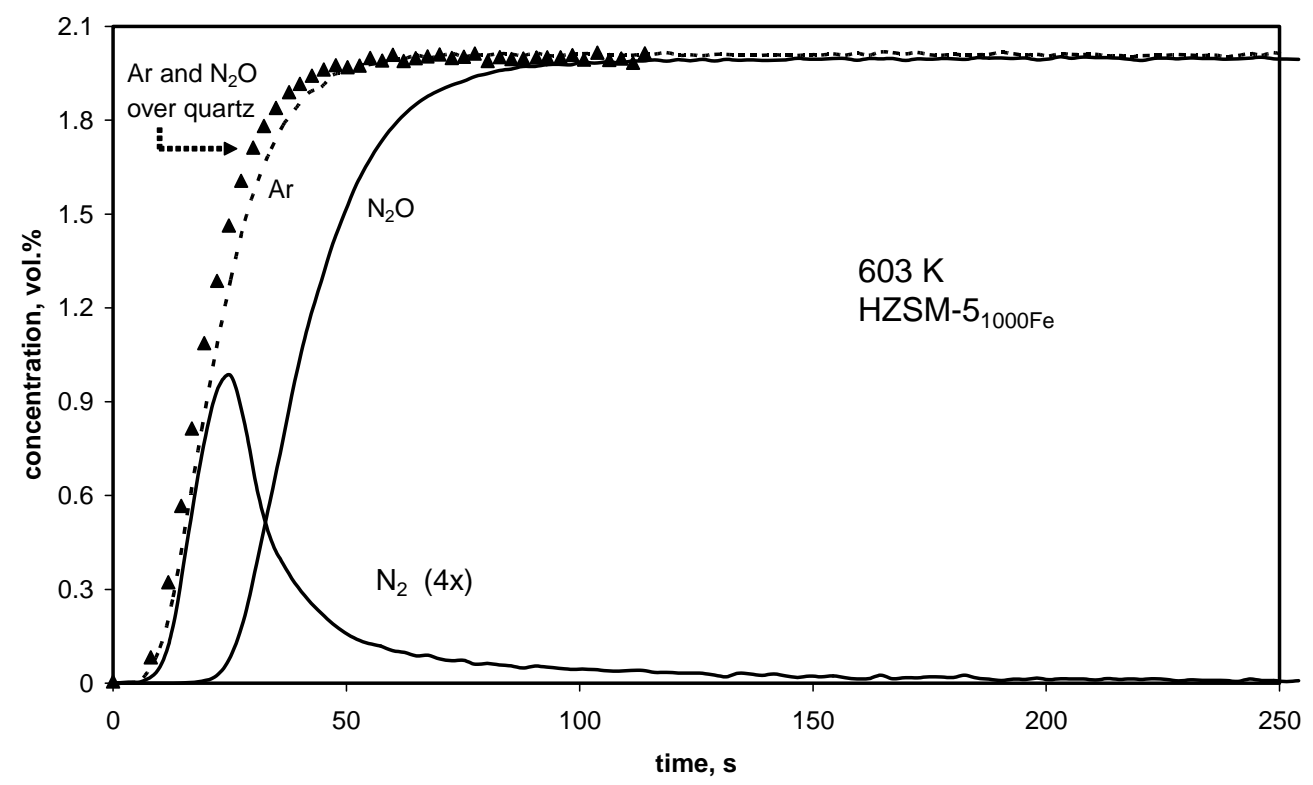

Fig. 1. Transient response curves obtained after introduction of the 2 vol.\% $\mathrm{N}_{2} \mathrm{O}, 2$ vol.\% Ar mixture in He on quartz beats ( $\left.\mathbf{\Delta}\right)$, HZSM-5 $1000 \mathrm{Fe}$ at $603 \mathrm{~K}$ after standard activation and pre-treatment in $\mathrm{He}$ at $823 \mathrm{~K}$ for $1 \mathrm{~h}$. 
repeated. No evolution of $\mathrm{N}_{2}$ was detected indicating that the formation of adsorbed oxygen was irreversible.

\subsection{Effect of the catalyst pre-treatment on the formation of active Fe-sites}

The catalytic activities of Fe-containing HZSM-5 have been reported to be strongly dependent on the pre-treatment conditions (catalyst activation), like temperature, time, and the gas atmosphere used. Therefore, after "standard pre-treatment" the calcination in He flow was performed during $1 \mathrm{~h}$ at different temperatures and the $C_{\mathrm{Fe}}$ concentration was measured by transient response method. The results for HZSM- $5_{200 \mathrm{Fe}}$ are presented in Fig. 2 showing $C_{\mathrm{Fe}}$ as a function of the pre-treatment temperature and time. The temperature increase from 823 to $1023 \mathrm{~K}$ does not change the amount of active sites, heating further to $1173 \mathrm{~K}$ doubled their amount, and the calcination at $1323 \mathrm{~K}$ results in a drastic concentration change of more than one order of magnitude (from $1.1 \times 10^{17}$ to $1.2 \times 10^{18} \mathrm{sites} / \mathrm{g}$ ). If the calcination at $1323 \mathrm{~K}$ was performed for $8 \mathrm{~h}$, the $C_{\text {ad }}$ increased up to $2.1 \pm 0.1 \times 10^{18}$ sites $/ \mathrm{g}$ and reached the stoichiometric maximum for the sample HZSM-5200Fe with the total amount of Fe-atoms of $2.14 \times 10^{18}$ atoms/g. It is important to note that the active Fe-sites once formed do not disappear due to re-hydroxylation. The sample HZSM-5 $200 \mathrm{Fe}$ after calcinations in $\mathrm{He}$ at $1323 \mathrm{~K}$ for $8 \mathrm{~h}$ was exposed for an ambient atmosphere, and even saturated by water vapors at $473 \mathrm{~K}$, but after standard calcinations at $823 \mathrm{~K}$ for $1 \mathrm{~h}$ the same amount of $C_{\mathrm{Fe}}=$ $(2.0 \pm 0.1) \times 10^{18}$ sites $/ g$ was detected. So, the isomorphously substituted zeolites with $\mathrm{Fe}$ in the framework must be pre-activated by mild steaming followed by high temperature calcination in an inert (see Fig. 2). Water vapor was reported to accelerate the hydrolysis of $\mathrm{Si}-\mathrm{O}-\mathrm{Fe}$ bonds, leading to $\mathrm{Fe}$ ex-framework formation as a single oxo-cations $\left([\mathrm{FeO}]^{+}\right.$, or $\left[\mathrm{Fe}(\mathrm{OH})_{2}\right]^{+}[10,11]$. Surface migration of iron may lead to the binuclear Fe-center $\mathbf{I}$ (see Scheme 1), and its presence in FeZSM-5 has been proven experimentally [12]. Calcination in inert at high temperature leads to dehydroxylation and auto-reduction of binuclear center I, forming structure II according to the scheme.

The influence of water on the concentration of oxygen $(\mathrm{O})_{\mathrm{ad}}$ deposited from $\mathrm{N}_{2} \mathrm{O}$ was studied. After the active $\mathrm{Fe}$-sites formation was completed, the HZSM-5 $200 \mathrm{Fe}$ was cooled down to $523 \mathrm{~K}$ and water was introduced into the reactor until saturation. The transient responses are presented in Fig. 3. It is seen that the $(\mathrm{O})_{\mathrm{ad}}$ concentration deposited on the sample saturated by water was much less as compared to the "dry" sample being $(1.0 \pm 0.05) \times 10^{18}$ atoms/g. This corresponds to about half of the active Fe-sites measured over "dry" HZSM- $5_{200 \mathrm{Fe}}$. It is interesting to note that only a half of sites are blocked by water and another half is still reactive towards $\mathrm{N}_{2} \mathrm{O}$ decomposition. In order to verify if this effect is valid for other catalysts, the $(\mathrm{O})_{\text {ad }}$ concentration was measured on the sample HZSM- $5_{1000 \mathrm{Fe}}$ before and after saturation by water as described above. The value $C_{\text {ad }}=(0.5 \pm 0.05) \times 10^{18}$ sites $/ g$ was obtained on "wet" zeolite in comparison with $C_{\mathrm{ad}}=(1.0 \pm 0.05) \times 10^{18} \mathrm{sites} / \mathrm{g}$ measured on the "dry" sample pre-treated in $\mathrm{He}$ at $1323 \mathrm{~K}$ for $17 \mathrm{~h}$. We consider this result as indirect sign of paired arrangement of $\mathrm{Fe}$-atoms in the active center. The structure of binuclear Fe-complex II requires an Al-centered tetrahedral configuration in its vicinity for charge compensation. In the scheme this is represented as $Z^{-}$indicating that the zeolite framework itself $\left[(\mathrm{Si}, \mathrm{Al}) \mathrm{O}_{n}\right]^{-}$acts as a crystalline acidic anion [13].

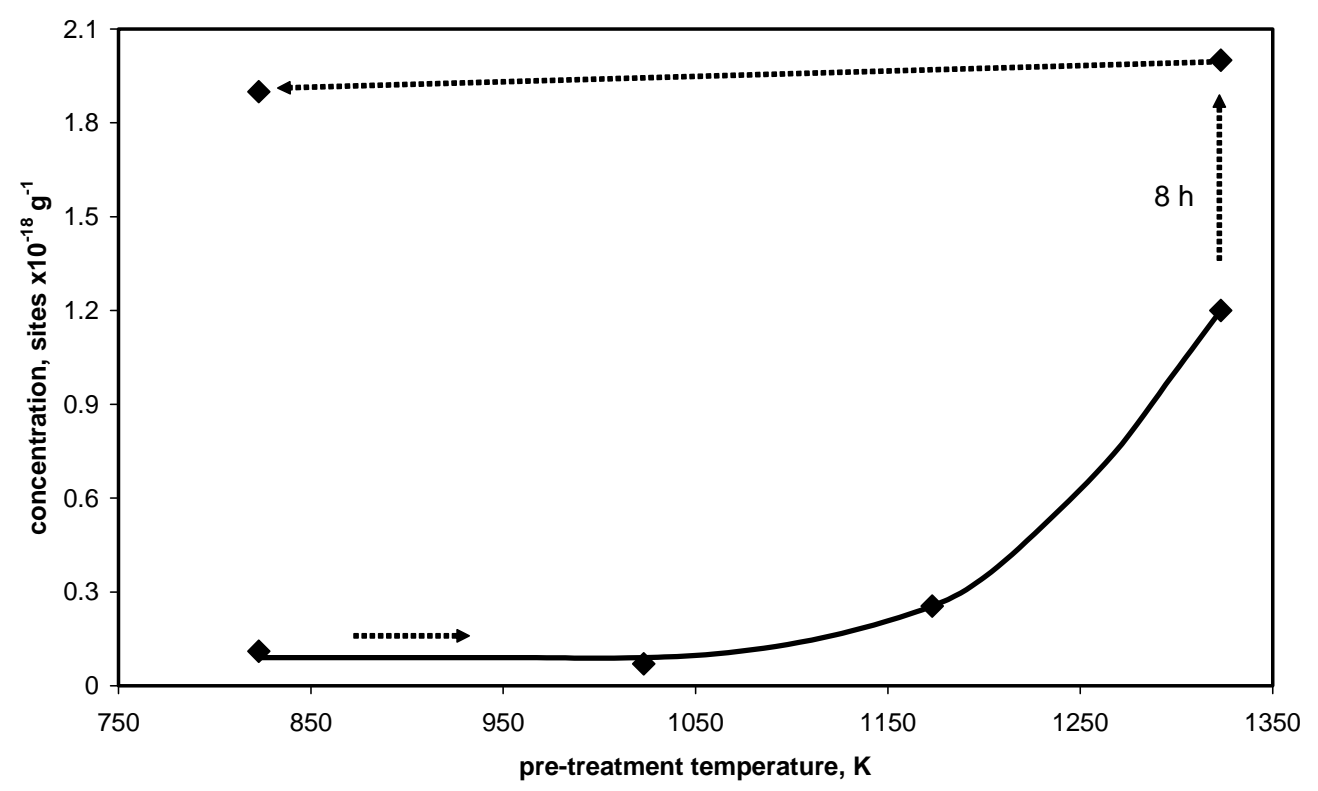

Fig. 2. Effect of the pre-treatment temperature (in He) and time on the concentration of active sites in the HZSM-5 $200 \mathrm{Fe}$ catalyst. 


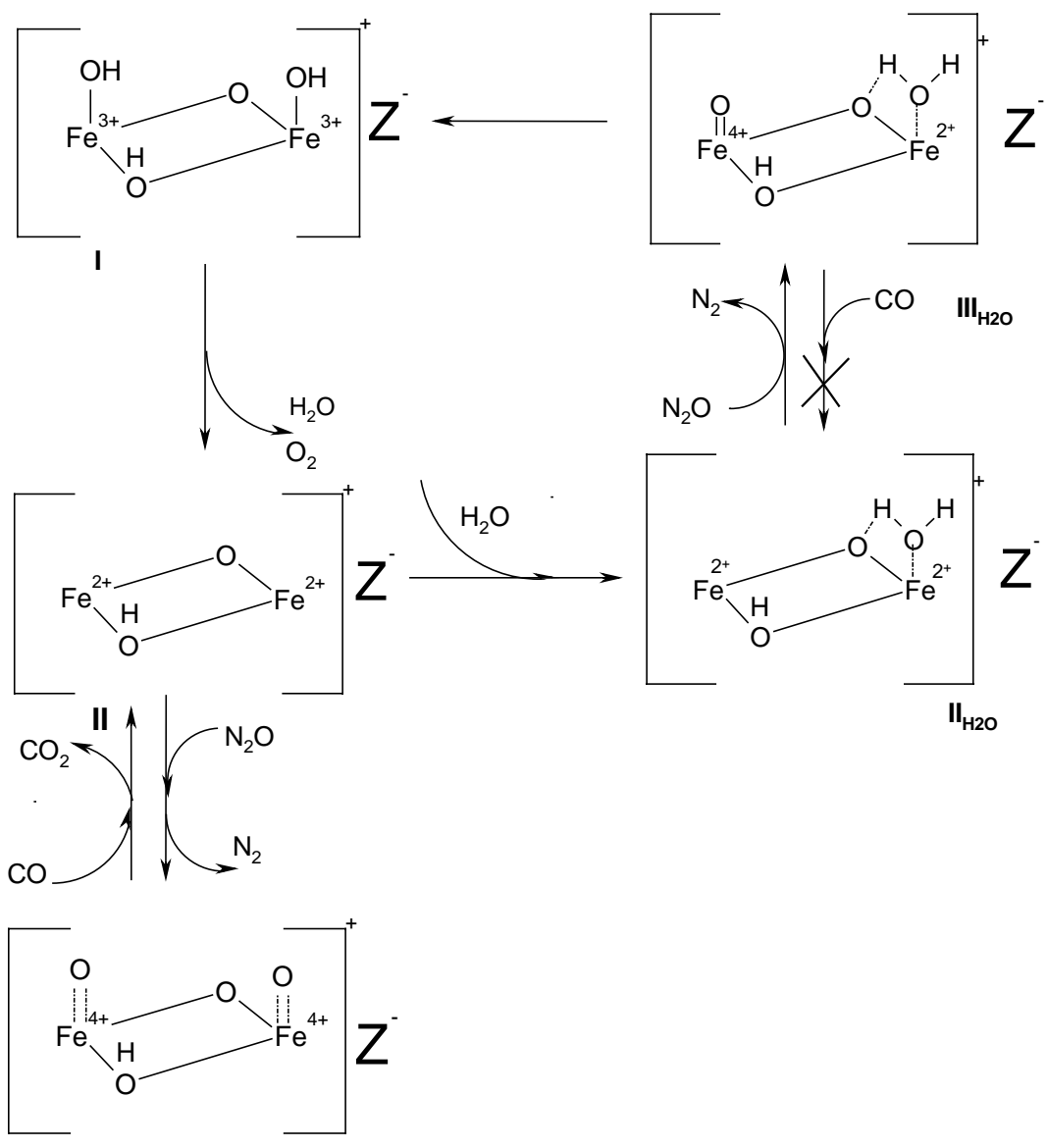

III

Scheme 1. Structure of $\left[\mathrm{Fe}_{2} \mathrm{O}_{2} \mathrm{H}^{+}\right]$-cluster formed during high temperature calcinations of $\mathrm{ZSM}-5_{200 \mathrm{Fe}}$ in inert flow and formation from $\mathrm{N}_{2} \mathrm{O}$ of paired $(\mathrm{O})_{\text {ad }}^{\text {act }}$ species active in $\mathrm{CO}$ oxidation (III). Pathway of water interaction with $\left[\mathrm{Fe}_{2} \mathrm{O}_{2} \mathrm{H}^{+}\right]$-clusters leading to the zeolite inactive in $\mathrm{CO}$ oxidation.

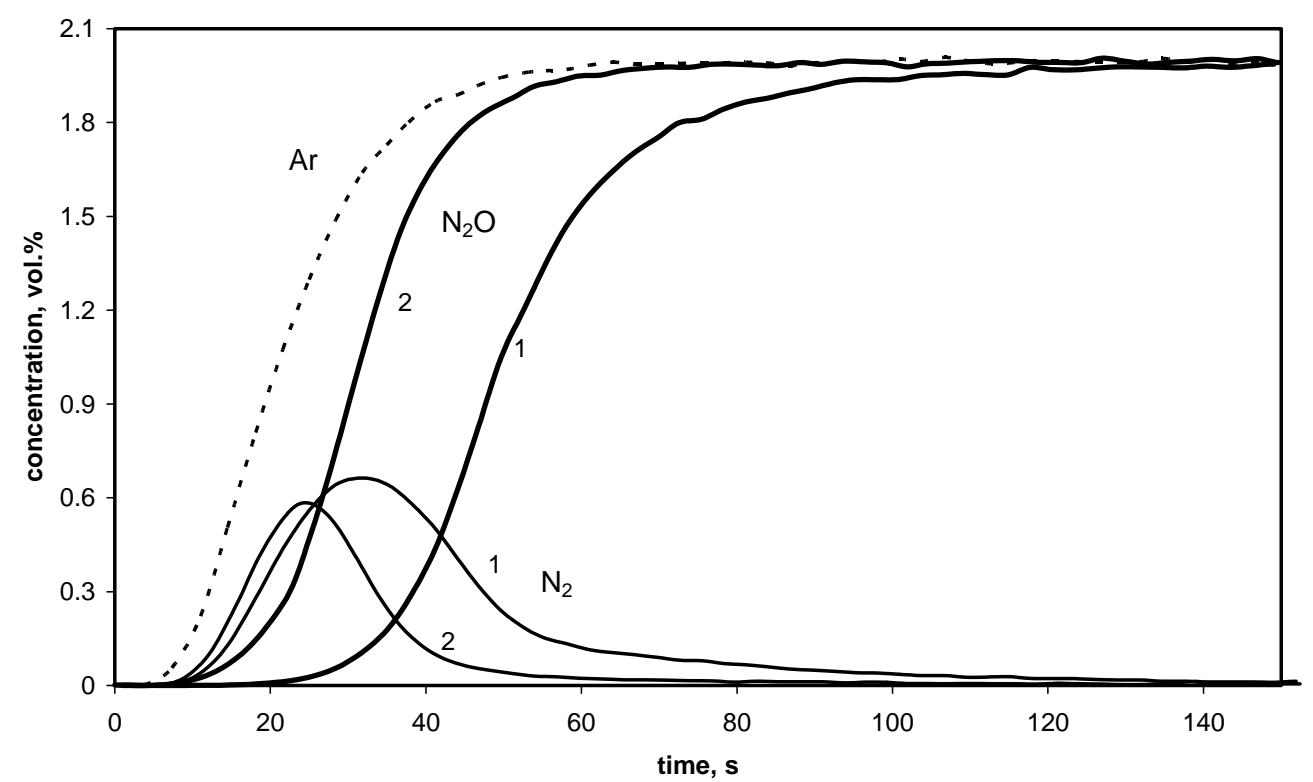

Fig. 3. Transient response curves obtained after introduction of the 2 vol. $\% \mathrm{~N}_{2} \mathrm{O}, 2$ vol. $\%$ Ar mixture in $\mathrm{He}$ on $\mathrm{HZSM}-5_{200 \mathrm{Fe}}$ at $523 \mathrm{~K}$ after the pre-treatment in $\mathrm{He}$ at $1323 \mathrm{~K}$ (1) and after the same pre-treatment followed by pre-saturation by water vapor at $523 \mathrm{~K}(2)$. 


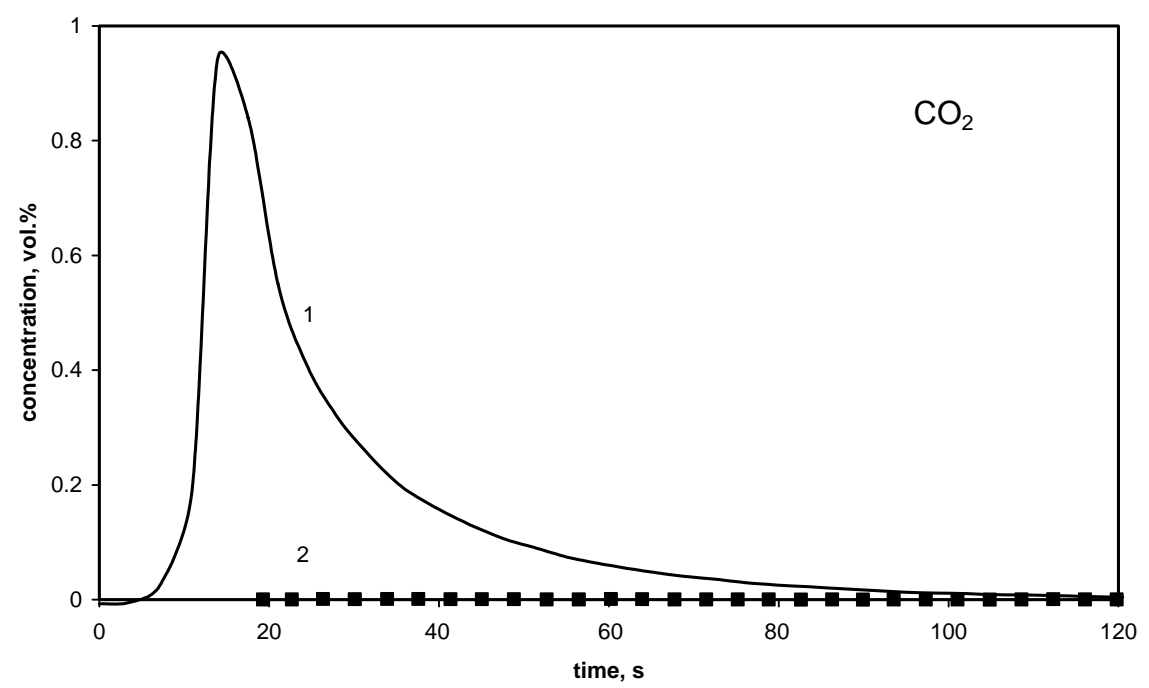

Fig. 4. $\mathrm{CO}_{2}$ response curves obtained during interaction of $\mathrm{CO}$ ( 3 vol. $\% \mathrm{CO}$ in $\mathrm{He}, 523 \mathrm{~K}$ ) with oxygen deposited from $\mathrm{N}_{2} \mathrm{O}$ on the $\mathrm{HZSM}-5_{200 \mathrm{Fe}}$ catalyst at $523 \mathrm{~K}$ after the pre-treatment in $\mathrm{He}$ at $1323 \mathrm{~K}$ (1) and after the same pre-treatment in He followed by pre-saturation with water vapor $\left(3.1 \times 10^{19} \mathrm{molecules} / \mathrm{g}\right)$ at $523 \mathrm{~K}(2)$.

\subsection{Reactivity of $(O)_{\text {ad }}$ in $\mathrm{CO}$ oxidation}

The main particularity of the oxygen species formed by $\mathrm{N}_{2} \mathrm{O}$ decomposition during its contact with $\mathrm{H}(\mathrm{Fe}) \mathrm{ZSM}-5$, is a high reactivity in oxidation reactions [14]. In the present study, the activity of $(\mathrm{O})_{\text {ad }}$ was characterized by its ability to oxidize $\mathrm{CO}$. The $\mathrm{CO}_{2}$ responses during the $\mathrm{CO}$ interaction with the catalyst containing $(\mathrm{O})_{\mathrm{ad}}$ deposited from $\mathrm{N}_{2} \mathrm{O}$ are presented in Fig. 4 for the sample pre-saturated and not with water before oxygen deposition from $\mathrm{N}_{2} \mathrm{O}$. If $(\mathrm{O})_{\mathrm{ad}}$ is formed on "dry" zeolite, a quick formation of $\mathrm{CO}_{2}$ was seen. The integration of the peak area gives the total amount of $\mathrm{CO}_{2}$ produced and characterizes the zeolite reactivity. For the "dry" zeolite the total amount of the $(\mathrm{O})_{\mathrm{ad}}^{\text {act }}$ consumed (or $\mathrm{CO}_{2}$ formed) corresponds to about $65 \%$ of the total amount of $(\mathrm{O})_{\mathrm{ad}}$ chemisorbed from $\mathrm{N}_{2} \mathrm{O}\left(C_{\mathrm{Fe}}\right)$. This means that the pool of deposited oxygen $(\mathrm{O})_{\mathrm{ad}}$ consists of two different sub-pools: one with the oxygen capable of reacting with $\mathrm{CO}\left((\mathrm{O})_{\mathrm{ad}}^{\text {act }}\right)$ and the other sub-pool with the inactive oxygen $\left.((\mathrm{O}))_{\mathrm{ad}}^{\text {inac }}\right)$. Pre-saturation of zeolites with water drastically affects the surface reactivity: the oxygen species become inactive. Thus, after HZSM-5 $200 \mathrm{Fe}$ pre-saturation by water only half of oxygen was deposited $\left(C_{\mathrm{Fe}}=1.1 \times 10^{18}\right.$ sites $\left./ \mathrm{g}\right)$, if compared to the "dry" zeolite and this oxygen species was not active for $\mathrm{CO}$ oxidation (Fig. 4, curve 2).

To explain the results obtain, we suggest the structure III formed with two terminal ferryl groups $[\mathrm{Fe}=\mathrm{O}]$ when the structure II reacts with $\mathrm{N}_{2} \mathrm{O}$. This is in line with the prediction by DFT analysis for a terminal $\mathrm{Fe}-\mathrm{O}$ group distance of $1.61 \AA$, indicating strong double-bond character [15]. We assume that $\mathrm{CO}$ interacts with the active terminal oxygen atoms forming $\mathrm{CO}_{2}$. The adsorption of one water molecule proceeds on two neighboring sites $\left(\mathrm{O}-\mathrm{Fe}^{2+}-\right)$ forming structure $\mathbf{I I}_{\mathrm{H}_{2} \mathrm{O}}$, and the binuclear Fe-center becomes a single Fe-site. Therefore, the remaining part of the binuclear "diamond core" cannot accept a second $\mathrm{H}_{2} \mathrm{O}$ molecule. But it is able to adsorb $\mathrm{N}_{2} \mathrm{O}$ forming terminal oxygen in the structure $\mathbf{I I I}_{\mathrm{H}_{2} \mathrm{O}}$ and releasing $\mathrm{N}_{2}$. The assumption about $\mathrm{H}_{2} \mathrm{O}$ blocking half of Fe-atoms may explain "a magic number" of $0.5 \times C_{\mathrm{Fe}}$ obtained after saturation by water. Hydroxylated form of binuclear Fe-center acts as a single $\mathrm{Fe}$-site, in agreement with the results of DFT calculations [15], which showed that the hydroxylated form of binuclear $\mathrm{Fe}$-center consists of one $\mathrm{Fe}$-ion completely saturated by water in the first coordination sphere. The result with $\mathrm{H}_{2} \mathrm{O}$ blocking one half of Fe-atoms also indirectly confirms the presence of proton in the binuclear "diamond core", since otherwise two molecules of $\mathrm{H}_{2} \mathrm{O}$ could be accommodated during adsorption on a $\left[\mathrm{Fe}_{2} \mathrm{O}_{2}\right]^{2+}$-center.

The structure of the binuclear $\mathrm{Fe}$-center proposed explains the results obtained for the activity of $(\mathrm{O})_{\mathrm{ad}}$ in $\mathrm{CO}$ oxidation. As shown in Scheme 1, structure II can accept two O-atoms leading to the form III with active terminal oxygen atoms able to form $\mathrm{CO}_{2}$. Only paired terminal $\mathrm{O}$-atoms adsorbed on the $\mathrm{Fe}$-sites of the binuclear center $\left[\mathrm{Fe}_{2} \mathrm{O}_{2} \mathrm{H}\right]^{+}$seem to be active in $\mathrm{CO}$ interaction, and the single $\mathrm{O}_{\mathrm{ad}}$-atoms generated on Fe-site in the hydroxylated binuclear complex $\left(\mathbf{I I I}_{\mathrm{H}_{2} \mathrm{O}}\right)$ are inactive. This result is in variance with the recently reported by Pérez-Ramírez et al. [16] high activity of isolated ex-framework iron sites in $\mathrm{N}_{2} \mathrm{O}$ reduction by $\mathrm{CO}$. This leads us to the conclusion that the inactivity of single $\mathrm{O}_{\mathrm{ad}}$-atoms in the complex ( $\mathbf{I I I}_{\mathrm{H}_{2} \mathrm{O}}$ ) may be due to (i) the necessity of $\mathrm{CO}$ activation via adsorption, which becomes impossible in the complex saturated by water, or (ii) the instability of the structure $\mathbf{I I I}_{\mathrm{H}_{2} \mathrm{O}}$ due to easy electron transfer from $\mathrm{Fe}^{2+}$ to $\mathrm{Fe}^{4+}$ resulting in the structure $\mathbf{I}$ consisting of two $\mathrm{Fe}^{3+}$. 


\section{Conclusions}

1. A transient response method is shown to be suitable for quantitative determination of the active Fe-sites during catalytic $\mathrm{N}_{2} \mathrm{O}$ decomposition with a sensitivity level up to few dozens ppm of Fe.

2. The surface active Fe-sites in isomorphously substituted $\mathrm{H}(\mathrm{Fe}) \mathrm{ZSM}-5$ are formed by mild steaming followed by high temperature calcinations in inert atmosphere.

3. A tentative structure of active binuclear Fe-center is proposed featuring a "diamond core" geometry, similar to that of the monooxygenase enzyme, which includes one $\mathrm{H}^{+}$-ion and has an overall monopositive charge $\left[\mathrm{Fe}_{2} \mathrm{O}_{2} \mathrm{H}\right]^{+}$.

4. Not all of $(\mathrm{O})_{\text {ad }}$-atoms deposited from $\mathrm{N}_{2} \mathrm{O}$ were active in $\mathrm{CO}$ oxidation at $523 \mathrm{~K}$ : only $\sim 65 \%$ corresponded to $(\mathrm{O})_{\text {ad }}^{\text {act }}$ and the rest were inactive.

5. $\mathrm{H}(\mathrm{Fe}) \mathrm{ZSM}-5$ pre-saturated by water generates oxygen species inactive in $\mathrm{CO}$ oxidation, suggesting either the necessity of $\mathrm{CO}$ activation via adsorption, which becomes impossible in the complex saturated by water, or irreversible transformation of $\mathrm{Fe}^{2+}$ to $\mathrm{Fe}^{3+}$ due to oxidation by $\mathrm{N}_{2} \mathrm{O}$ in the presence of water.

\section{References}

[1] K.A. Dubkov, N.S. Ovanesyan, A.A. Shteinman, E.V. Starokon, G.I. Panov, J. Catal. 207 (2002) 341.

[2] G.I. Panov, Cattech. 4 (2000) 18.

[3] J. Perez-Ramirez, G. Mul, F. Kapteijn, J.A. Moulijn, A.R. Overweg, A. Domenech, A. Ribera, I. Arends, J. Catal. 207 (2002) 113.

[4] Q. Zhu, B.L. Mojet, R.A.J. Janssen, E.J.M. Hensen, J. van Grondelle, P. Magusin, R.A. van Santen, Catal. Lett. 81 (2002) 205.

[5] P. Kubanek, B. Wichterlova, Z. Sobalik, J. Catal. 211 (2002) 109.

[6] M.J. Rice, A.K. Chakraborty, A.T. Bell, J. Catal. 186 (1999) 222.

[7] A.A. Shubin, G.M. Zhidomirov, A.L. Yakovlev, R.A. van-Santen, J. Phys. Chem. 105 (2001) 4928.

[8] N.A. Kachurovskaya, G.M. Zhidomirov, E.J.M. Hensen, R.A. van-Santen, Catal. Lett. 86 (2003) 25.

[9] L. Kiwi-Minsker, D.A. Bulushev, A. Renken, J. Catal. 219 (2003) 273.

[10] J.A. Ryder, A.K. Chakraborty, A.T. Bell, J. Phys. Chem. B 106 (2002) 7059.

[11] E.M. El-Malki, R.A. van Santen, W.M.H. Sachtler, J. Catal. 196 (2000) 212

[12] P. Marturano, L. Drozdova, A. Kogelbauer, R. Prins, J. Catal. 192 (2000) 236

[13] A. Corma, Chem. Rev. 95 (1995) 559.

[14] G.I. Panov, A.K. Uriarte, M.A. Rodkin, V.I. Sobolev, Catal. Today 41 (1998) 365.

[15] A.L. Yakovlev, G.M. Zhidomirov, R.A. van Santen, J. Phys. Chem. B 105 (2001) 12297.

[16] J. Pérez-Ramírez, F. Kapteijn, A. Bruckner, J. Catal. 218 (2003) 234. 